\title{
STRUKTUR DAN POLA KEPEMIMPINAN KYAI DALAM PESANTREN DI JAWA
}

\author{
Amir Fadhilah \\ UIN Syarif Hidayatullah, Jl. Ir. H. Juanda No. 95 Ciputat 15412 \\ E-mail: fadhi_uin@yahoo.com
}

\begin{abstract}
Abstrak: Dunia pesantren dan kharisma kyai merupakan salah satu fenomena yang menarik untuk dikaji. Corak kehidupan kyai dan santri yang demikian besar membuat pesantren berfungsi multi dimensi: kyai tidak hanya berperan sebagai imam di bidang ubudiah dan ritual upacara keagamaan saja, namun sering pula diminta kehadirannya untuk menyelesaikan perkara atau kesulitan yang menimpa masyarakat. Dalam kontek ini peran kyai semakin mengakar di masyarakat ketika kehadirannya diyakini membawa berkah. Keberadaan struktur dan pola kekuasaan (kepemimpinan) kyai dalam hasanah dunia pesantren tetap berkesinambungan, karena kyai memiliki jaring-jaring sosial yang terikat secara internal (kalangan pesantren) maupun secara ekternal (dengan dunia luar pesantren), meliputi jaringan genealogis, Jaringan ideologis, jaringan intelektual, jaringan teologis. dan jaringan spiritual.
\end{abstract}

Abstract: The world of pesantren and the Islamic clerics' charisma is one of the interesting phenomena to be studied. The style of clerics' life and religious students is so great that it makes Islamic boarding school posess a multi-dimensional function: The Kyais not only are not only required as priests in religious ceremonies and rituals, but also often required her presence to resolve the case or the difficulties that befall the community. In this context, the role of the Islamic clerics is increasingly rooted in the community when their presences are believed to bring fortune. The existence of structures and patterns of authority (leadership) clerics in the Islamic world remain sustainable, because the Islamic clerics have internal social nets (among the religious schools) and external social netwoeks (with the world outside pesantren), includes genealogical network, ideological network, intellectual network, theological network, and spiritual network. 
Kata Kunci: pola kepemimpinan kyai, pesantren, kharismatik dan jaringan

\section{PENDAHULUAN}

Salah satu lembaga pendidikan yang sudah cukup lama di Indonesia adalah pondok pesantren. Lembaga ini dalam konteks sosio historis banyak menyumbangkan andilnya dalam membentuk serta membangun bangsa. Walaupun tradisi di pondok pesantren merupakan sistem pendidikan Islam tradisional, dalam perjalan sejarahnya telah menjadi objek penelitian para sarjana yang mempelajari Islam di Indonesia. Hal ini menunjukkan bahwa pesantren memiliki pengaruh yang cukup kuat dalam membentuk dan memelihara kehidupan sosial, kultural, politik dan khsusunya keagamaan.

Sebagai lembaga pendidikan tradisional umat Islam, pondok pesantren yang bertujuan mempelajari, memahami, mendalami, menghayati dan mengamalkan ajaran Islam dengan memberikan tekanan pada keseimbangan aspek perilaku (ahklak). Di Indonesia, sejak permulaan abad ke-16 telah banyak dijumpai pesantren yang mengajarkan berbagai kitab Islam klasik dalam bidang fikih, teologi dan tasawuf ${ }^{1}$. Di sisi, lain pesantren juga menjadi pusat penyiaran Islam di tanah air.

Hubungan yang kuat antara ulama (kyai) dan umat Islam tampak jelas dalam pertumbuhan dan perkembangan masyarakat Islam. Peran sosial kemasyarakatan ulama (kyai) di tengah-tengah kehidupan masyarakat baik menyangkut aspek sosial, politik, kebudayaan maupun yang lebih spesifik adalah bidang keagamaan, paling tidak telah menjadikan kyai sebagai sosok dan figur terpandang dalam masyarakat.

Dalam lingkup masyarakat agraris terdapat hubungan yang erat antara masyarakat dan para ulama (kyai). Hal ini terjadi

\footnotetext{
${ }^{1}$ Amin Suma,dkk, Pondok Pesantren Al-Zaytun: Idealitas, Realitas dan Kontroversi, (Jakarta: Lembaga Penelitian Universitas Islam Negeri (UIN) Syarif Hidayatullah, 2002), h. 3.
} 
karena biasanya para ulama (kyai) memiliki identitas yang sama dengan khalayak lingkungannya, umpamanya sebagai petani. ${ }^{2}$ Dengan kesamaan tersebut, komunikasi antara kyai dengan masyarakat sekitarnya terjalin dengan akrab. Di sisi lain, kelebihan yang dimiliki kyai sebagai elit religius berpengaruh besar terhadap masyarakat di sekitarnya yang menjadikannya sebagai key person dalam komunitas tersebut.

Pondok pesantren yang merupakan lembaga pendidikan Islam mapan dan juga lembaga yang masih berperan aktif membina sosio-budaya bangsa, terutama untuk mereka yang dididik di dalamnya. Sampai saat ini lembaga tersebut masih menunjukkan kemampuannya untuk memelihara nilai-nilai luhur ajaran Islam, sehingga menjadi modal utama yang sangat penting bagi pesantren. Sistem belajar sambil berbuat sejak fajar terbit sampai larut malam merupakan cara kerja orang pesantren. Adanya ciri-ciri kesederhanaan, persaudaraan yang akrab, keikhlasan, kemandirian, kegotongroyongan, jauh dari ketamakan dan mementingkan diri sendiri (egoisme) dan lain-lain adalah produk dari pembentukan kepribadian dalam pendidikan di pesantren

Dunia pesantren dan kharisma kyai merupakan salah satu fenomena yang menarik untuk dikaji, sebab bagaimanapun keberadaannya memiliki tempat tersendiri dalam masyarakat. Tidak disangkal lagi, khususnya bagi masyarakat Jawa, pondok pesantren dengan segala atributnya pernah menduduki posisi strategis. Pesantren mendapat pijakan sangat besar dan mampu menembus dinding kehidupan. Popularitas pondok pesantren bahkan dimitoskan oleh kharisma kyai dan dukungan santri yang tersebar di tengah kehidupan masyarakat. Corak kehidupan kyai dan santri yang demikian besar membuat pesantren berfungsi multi dimensi: kyai tidak hanya berperan sebagai imam di

${ }^{2}$ Sartono Kartodirdjo, Kepemimpinan dalam Sejarah Indonesia (Yogyakarta: BPA UGM, 1974). 
bidang ubudiah dan ritual upacara keagamaan, namun sering pula diminta kehadirannya untuk menyelesaikan perkara atau kesulitan yang menimpa masyarakat. Seorang kyai misalnya, tidak jarang diminta mengobati orang sakit, memberi serangkaian ceramah bahkan dimintakan doa untuk keselamatan mereka. Dengan demikian, peran kyai semakin mengakar di masyarakat ketika kehadirannya diyakini membawa berkah.

Meskipun kyai sering dikonotasikan sebagai kelompok tradisional, keberadaannya ternyata tidak dapat digantikan oleh tokoh non formal lainnya. Peranannya sebagai figur sentral merupakan fakta yang tidak perlu dipungkiri, khususnya di kalangan Nahdhiyyin. Bahkan visi dan misi keilmuan kyai dalam suatu pesantren beserta kualitas santrinya menjadi salah satu barometer penilaian masyarakat terhadapnya. ${ }^{3}$ Sedemikian kuat tipologi kyai dengan pesantrennya, sehingga transmisi dan pengembangan keilmuan dalam suatu pesantren kadang terlalu sulit dipisahkan dari tradisi keilmuan yang pernah diwariskan kyai pendahulu yang pernah menjadi gurunya.

Kharisma kyai yang memperoleh dukungan dan kedudukan di tengah kehidupan masyarakat terletak pada kemantapan sikap dan kualitas yang dimilikinya, sehingga melahirkan etika kepribadian penuh daya tarik. Proses ini bermula dari kalangan terdekat kemudian mampu menjalar ke tempat berjauhan. Kyai tidak hanya dikategorikan sebagai elit agama. ${ }^{4}$ Dalam konteks kehidupan pesantren, kyai juga menyandang sebutan elit pesantren yang memiliki otoritas tinggi dalam menyimpan dan menyebarkan pengetahuan keagamaan.

${ }^{3}$ Suwito, “Jaringan Intelektual Kyai Pesantren di Jawa-Madura Abad XX", dalam Khaeroni dkk (Eds.), Islam dan Hegemoni Sosial (Jakarta: Proyek Pengembangan Penelitian pada Perguruan Tinggi Agama Islam Direktorat Perguruan Tinggi Agama Islam Departemen Agama RI, 2001), h. 129

${ }^{4}$ Sukamto, "Kepemimpinan dan Struktur Kekuasaan Kyai: Studi Kasus Pondok Pesantren Darul Ulum Jombang” dalam Prisma No. 4 April 1997, Jakarta: LP3ES. 
Kyai ikut mewarnai corak dan bentuk kepemimpinan yang berlaku di pondok pesantren. Kharisma yang melekatpada dirnya tidak jarang dijadikan tolok ukur utama kewibawaan pokok pesantren. Dalam konteks ini meminjam pemikiran Weber yang menggambarkan pemimpin-pemimpin agama yang berkharismatik. Dasar kepemimpinan mereka adalah kepercayaan bahwa mereka memiliki suatu hubungan khusus dengan yang Maha Kuasa atau malah mewujudkan karakteristik-karakteristik ilahi tersebut. ${ }^{5}$ Sifat ini dipandang dari celah kehidupan santri sebagai satu-satunya karunia kekuasaan yang bersumber dari kekuatan Tuhan.

Khasanah riwayat pesantren menggambarkan betapa kuat pengaruh kharisma kyai, mereka menjadi kiblat para pengikutnya. Kebijakan yang seringkali dituangkan secara lisan dijadikan pegangan, sikap dan tingkahlakunya sehari-hari dijadikan panutan, bahasa kiasan yang dilontarkannya acapkali menjadi bahan renungan. Karena itu mekanisme administrasi pondok pesantren baik yang berkaitan dengan struktur organisasi kepemimpinan maupun arah perkembangan pesantren, tidak lepas dari peranan kyai. Dengan demikian, seringkali visi kyai merupakan barometer pondok pesantren.

Dalam perkembanganannya, sebagai lembaga pendidikan, pondok pesantren tentu tidak terlepas dari pengaruh sistem pendidikan nasional yang merembas ketengah-tengah komunitas pesantren, bagaimanapun lambat laun pengaruh tersebut lambat laun akan ikut mewarnai khasanah pendidikan pesantren. Aspek yang menarik dalam kontek ini adalah bagaimana kedudukan kyai dalam pondok pesantren dewasa ini apakah terpengaruh imbas modernisasi pendidikan nasional dalam arti apakah pola kepemimpinan kyai dalam pokok pesantren mengalami perubahan ?. Aspek ini yang menarik penulis untuk membahas

5ohson Doyle Paul, Teori Sosiologi Klasik dan Modern, terj. Robert M. Z. Lawang (Jakarta: PT Gramedia, 1994), h. 229. 
bagaimana struktur dan dan pola kekuasaan kyai dalam pesantren khususnya di masyarakat Jawa.

\section{PONDOK PESANTREN DI JAWA}

Pesantren di Jawa dikenal dengan sebutan pondok atau pondok pesantren, di Aceh dikenal dengan nama rangkang, sedangkan di Sumatera Barat lazim disebut langgar. Jika dilihat dari segi pengorganisasian dan sistem yang dipakai dalam Pesantren yang ada di Jawa dan Sumatera, banyak persamaanya dengan sistem asrama (sistem guru kula) di India. Kuat dugaan bahwa lembaga-lembaga pendidikan seperti itu telah ada jauh sebelum Agama Islam masuk ke Indonesia.

Pondok pesantren merupakan lembaga pendidikan khas Indonesia yang tumbuh dan berkembang di tengah-tengah masyarakat serta telah teruji kemandiriannya sejak dulu hingga sekarang. Pada awal berdirinya, bentuk pondok pesantren masih sangat sederhana, kegiatannya hanya diselenggarakan dalam masjid atau surau dengan beberapa orang santri yang kemudian berkembang dan ditempatkan di bagian pondok-pondok (asrama) sebagai tempat tinggal. Untuk menentukan kapan pondok pesantren pertama kali berdiri sangat sulit, namun dapat dikemukakan bahwa lahir dan tumbuhnya pondok pesantren tidak jauh berselang setelah Islam tersebar di nusantara.

Bukti-bukti tentang kapan pesantren pertama kali didirikan di Pulau Jawa belum ada i yang kuat untuk mengungkap hal tersebut. Wali Songo sebagai bagian dari penyebar Islam di Indonesia telah memberikan kontribusi banyak bagi berdirinya dunai pesantren. Dalam proses dakwahnya, mereka telah mendirikan masjid dan asrama (padepokan) untuk para santrinya. Seperti dicerikan dalam 'Babad Tanah Jawi', Sunan Ampel telah membangun lembaga pendidikan Islam untuk para generasi muda. Salah satu santrinya adalah Sunan Giri yang kemudian 
mendirikan lembaga pendidikan Islam di Giri. ${ }^{6}$. Bermula dari sini akhirnya bermunculan lembaga pendidikan Islam dan merupakan titik awal dari keberadaan sistem pendidikan pesantren di Jawa.

Seiring dengan perkembangan Islam di Nusantara pondok pesantren terus berkembang, dimana dalam prosesnya antara satu wilayah dengan wilayah lainnya berbeda-beda dari segi waktu dan bentuknya, sesuai dengan kondisi kuat atau lemahnya budaya pra Islam di daerah tersebut. Disamping itu, faktor tingkat intensitas interaksi suatu wilayah dengan dunia Islam ikut juga berpengaruh.

Pondok pesantren dalam perspektif historis tidak hanya mengandung makna keislamaan, tetapi juga keaslian (indigenous) Indonesia. Sebab lembaga yang serupa telah ada pada masa penyebaran agama Hindu-Budha, sedangkan Islam hanya meneruskan atau mengislamkannya. Dengan demikian pondok pesantren merupakan sebuah institusi pendidikan dan penyebaran Islam.

Kata pesantren sendiri berasal dari kata 'santri', dengan awal pe di depan dan akhiran an yang berarti tempat tinggal para santri. Term santri menurut C.C. Berg berasal dari istilah 'shastri' yang dalam bahasa India berarti orang yang tahu buku-buku suci agama atau seorang yang ahli kitab suci. Sedangkan menurut Nurcholis Majid, istilah santri dapat dibedakan menjadi dua. Pertama, kata santri berasal dari kata 'sastri' bahasa Sankskerta yang artinya melek huruf. Asumsi ini didasarkan bahwa kaum santri yang berusaha mendalami agama melalui kitab-kitab bertuliskan dan berbahasa Arab menyebabkan para santri harus berusaha belajar bahasa Arab dan kedua, kata santri berasal dari

${ }^{6}$ Badri Yatim, (dkk), Sejarah Perkembangan Madrasah (Jakarta: Direktorat Jenderal Pembinaan Kelembagaan Agama Islam Departemen Agama RI, 1999), h. 96. 
bahasa Jawa dari kata 'cantrik'yang berarti seseorang yang selalu mengikuti seorang guru kemana guru ini pergi menetap.

Pengertian terminologi pesantren di atas, mengindikasikan bahwa secara kultural pesantren lahir dari budaya Indonesia. Dengan demikian, pondok pesantren mengandung tidak hanya makna keislaman, tetapi juga makma keaslian Indonesia sebab cikal bakal institusi pesantren sudah ada sejak masa Hindu Budha di mana Islam hanyal meneruskan, melestarikan, dan mengislamkannya.

Hal senada juga di ungkapkan oleh Karel A. Steenbrink dalam bukunya: 'Pesantren Madrasah Sekolah : Pendidikan Islam dalam Kurun Moderen' 8 yang menyatakan bahwa secara terminologi dapat dijelaskan bahwa pendidikan pesantren, di lihat dari segi bentuk dan sistemnya, berasal dari India, sebelum proses penyebaran Islam di Indonesia, sistem tersebut telah dipergunakan secara umum untuk pendidikan dan pengajaran agama Hindu di Jawa. Setelah Islam masuk dan tersebar di Jawa, sistem tersebut kemudian diambil oleh Islam.

Pesantren, sebagai lembaga pendidikan dan keagamaan Islam yang mengakar pada masyarakat dan memilki posisi strategis dalam upaya pengembangan umat dan mempersiapkan sumberdaya manusia Indonesia yang tangguh dan mandiri, maka tidak mengherankan bila perhatian berbagai pihak kian meningkat, terutama dikaitkan dengan eksistensi pondok pesantren yang dapat memainkan peranan sebagai sentra pengembangan masyarakat. ${ }^{9}$ Karena peran yang diembannya

\footnotetext{
1997), h. 16.

${ }^{8}$ Karel A. Steenbrink, Pesantren Madrasah Sekolah: Pendidikan Islam dalam Kurun Moderen. terj. Karel A. Steenbrink dan Abdurrahman (Jakarta: LP3ES, 1994), h 67.

${ }^{9}$ Husni Rahim, Direktori Pondok Pesantren (Jakarta: Proyek Peningkatan Pondok Pesantren Tahun Anggaran 2000 Direktorat Jenderal Pembinaan Kelembagaan Agama Islam Departemen Agama RI, 2000), h. v.
}

${ }^{7}$ Nurcholish Madjid, Kaki Langit Peradaban Islam (Jakarta: Paramadina, 
begitu besar maka makin besar pula tantangan yang mesti dihadapi dan dijawab oleh pondok pesantren.

\section{ELEMEN-ELEMEN PONDOK PESANTREN DI JAWA}

Pesantren pada umumnya terdiri atas lima elemen pokok, yaitu: kyai, santri, masjid, pondok dan pengajaran kitab-kitab Islam klasik. Kelima ciri tersebut merupakan ciri khusus yang dimiliki pesantren dan membedakan pondok pesantren dengan lembaga pendidikan lainnya.

\section{Pondok}

Di kawasan Nusantara istilah pesantren lebih popular dengan sebutan pondok pesantren. Lain halnya dengan pesantren, pondok berasal dari bahasa Arab 'fundoq' yang berarti asrama, rumah dan tempat tinggal. ${ }^{10}$ Pondok dalam pesantren pada dasarnya merupakan dua kata yang penyebutannya sering tidak dipisahkan menjadi 'pondok pesantren', yang berarti keberadaan pondok dalam pesantren merupakan wadah penggemblengan, pembinaan dan pendidikan serta pengajaran ilmu pengetahuan.

Kedudukan pondok pesantren bagi para santri sangat esensial sebab di dalamnya santri tinggal dan belajar serta ditempa pribadinya dengan kontrol seorang ketua asrama (santri senior) atau kyai yang memimpin pesantren tersebut. Paling tidak ada tiga alasan utama mengapa pesantren harus mempunyai pondok (asrama) $)^{11}$, yaitu : (1) kemasyhuran seorang kyai dan kedalaman pengetahuannya tentang Islam menarik santri-santri jauh. Agar para santri dapat mempelajarai ilmu dari sang kyai dengan teratur, lancar dan baik ia harus tinggal di kediaman kyai (pondok); (2) hampir semua pesantren berada di desa di mana

${ }^{10}$ Hasbullah, Sejarah Pendidikan Islam di Indonesia: Lintas Sejarah Pertumbuhan dan Perkembangan (Cet. ke-2; Jakarta: Raja Grafindo Persada, 1996), h. 138.

${ }^{11}$ Yatim, (dkk), Sejarah Perkembangan ..., h. 98. 
tidak tersedia perumahan yang cukup untuk menampung santri. Sehingga diperlukan pondok sebagai asrama khsusus santri; dan (3) ada sikap timbal balik antara kyai dan santri, di mana santri menganggap kyainya seolah-olah sebagai orang tuanya sendiri, begitu pula sebaliknya untuk mendidik para santri, dan sebaliknya kyai menganggap para santri sebagai titipan ilahi yang harus dibina sepenuh hati.

Sebuah pesantren pada dasarnya merupakan tempat atau asrama bagi para santrinya. Karena santri tinggal di pondok, kyai akan lebih mudah mendidik dan mengajarkan segala jenis ilmu pengetahuan sesuai dengan kurikulum yang ditetapkannya.

Kyai

Ciri yang paling esensial bagi suatu pesantren adalah adanya seorang kyai (Jawa) atau ajengan (Sunda). Kyai / Ajengan pada hakekatnya adalah gelar yang diberikan kepada seseorang yang mempunyai ilmu di bidang agama dalam konteks ini agama Islam. Ia merupakan pelopor bagi kelahiran pesantren yang dipimpinnya dan menjadi pemegang serta penentu kebijakan yang ada di seluruh pesantren.

\section{Santri}

Istilah santri hanya terdapat di pesantren sebagai pengejawantahan adanya peserta didik yang haus akan ilmu pengetahuan yang dimiliki oleh seorang kyai yang memimpin sebuah pesantren. Oleh karena itu santri pada dasarnya berkaitan erat dengan keberadaan kyai dan pesantren.Dalam tradisi pesantren, santri sering kali dibedakan menjadi dua, yaitu santri mukim dan santri kalong.

Pertama, Santri Mukim, yaitu santri yang berasal dari tempat jauh di mana ia menetap dan tinggal serta secara aktif menuntut ilmu dari seorang kyai. Dapat juga secara langsung sebagai pengurus pesantren yang ikut bertanggungjawab atas keberadaaan santri lainnya. Ada dua motif yang mendasari 
seorang santri menetap sebagai santri musim, ${ }^{12}$ yaitu: (1) motif menuntut ilmu artinya santri itu dating dengan maksud menuntut ilmu dari kyainya; dan (2) motif menjunjung tinggi akhlak, artinya seorang santri belajar secara tidak langsung agar santri tersebut setelah di pesantren akan memiliki akhlak yang terpuji sesuai yang diajarkan kyainya.

Kedua, Santri Kalong, yaitu santri yang berasal dari desa sekitar pondok pesantren, yang biasanya tidak menetap di dalam pondok pesantren, tetapi setelah belajar langsung kembali ke rumah masing-masing.

Biasanya perbedaan antara pesantren kecil dan pesantren besar dapat dilihat dari komposisi santri kalong, semakin besar sebuah pesantren akan semakin besar jumlah santri mukimnya. Dengan kata lain pesantren kecil akan lebih banyak memiliki santri kalong dibandingkan santri mukim.

\section{Masjid}

Kata masjid secara harfiah berarti tempat sujud, dari akar kata 'sajada' yang artinya bersujud. Dalam sejarah Islam, masjid memiliki fungsi yang sangat luas, bukan hanya tempat bersujud dalam arti ibadah semata seperti salat dan i'tikaf, tetapi juga berfungsi sebagai tempat berlangsungnya proses belajar mengajar.

Ketika Nabi Muhammad saw. hijrah dari Mekah ke Madinah, yang pertama ia bangun adalah masjid, yaitu Masjid Quba' ketika Rasulullah masih dalam perjalanan dan Masjid Nabawi ketika ia telah tiba di Madinah. Rasulullah menyadari bahwa masjid akan menjadi modal utama dalam melanjutkan misi dakwahnya untuk membangun masyarakat yang beradab. ${ }^{13}$ Dengan kata lain, Rasulullah mencontohkan bagaimana sebuah masjid dapat

\footnotetext{
${ }^{12}$ M. Bahri Ghazali, Pendidikan Pesantren Berwawasan Lingkungan (Jakarta: Penerbit Pedoman Ilmu Jaya, 2001), h. 23.

${ }^{13}$ Madjid, Kaki Langit ..., h. 34.
} 
bersifat multifungsi dan menjadi bagian penting dalam masyarakat Islam.

Masjid merupakan elemen yang tidak dapat dipisahkan dari dunia pesantren, sebab masjid dijadikan ajang sentral kegiatan dengan mencontoh pada teladan yang diberikan Rasulullah yang menjadikan masjid sebagai pusat segala aktivitas yang dilakukan melalui sarana ibadah ini, sebagaimana terlihat dalam pertumbuhan dan perkembangan sebuah pesantren. Di sini masjid sebagai pusat aktivitas kegiatan, baik pendidikan, dakwah, ibadah dan lain-lainnya. Agaknya disinilah letak manifestasi universalisme yang terdapat dalam sistem pendidikan Islam dalam hal ini pesantren.

\section{Pengajaran Kitab-kitab Islam Klasik}

Kitab-kitab Islam klasik biasanya dikenal dengan istilah 'kitab kuning' yang terpengaruh oleh warna kertas. Kitab-kitab tersebut ditulis oleh ulama-ulama zaman dulu yang berisikan tentang ilmu keislaman. Dalam hal ini terutama kitab-kitab karangan ulama yang beraliran Syafi'iyah. Kitab-kitab klasik tersebut pada umumnya dapat dikelompokkan ke dalam delapan bidang, yaitu: (1) Nahw dan șarf (tata bahasa Arab), (2) Fiqh, (3) Ușūl al-Fiqh, (4) Hadīś, (5) Tafsīr, (6) Tauhīd, (7) Tașawwuf dan etika, dan (8) cabang-cabang lain seperti tarikh (sejarah Islam) dan Balāghah (sastra Arab). Sistem pengajaran melalui 'kitabkitab kuning' telah menjadi karakteristik yang merupakan ciri khas dari proses belajar mengajar di pesantren. ${ }^{14}$ Kitab-kitab tersebut biasanya dikategorikan ke dalam tiga tingkatan, yaitu: (1) Kitab-kitab dasar, (2) Kitab-kitab menengah dan (3) kitab-kitab besar.

Proses mempelajari kitab-kitab klasik tersebut biasanya menggunakan sistem weton dan sorogan atau lebih kenal dengan

${ }^{14}$ Faisal Ismail, Paradigma Kebudayaan Islam: Studi Kritis dan Refleksi Historis (Cet. ke-2; Yogyakarta: Titian Ilahi Press, 1997), h. 116-117. 
'sorogan' dan 'bandungan'. Weton adalah pengajian yang inisiatifnya berasal dari kyai sendiri, baik dalam menentukan tempat, waktu maupun fokus bahasannya (kitabnya). Sedangkan sorogan merupakan pengajian yang diajukan oleh seseorang ataupun kelompok santri kepada kyainya untuk diajarkan kitab tertentu. Pengajian sistem sorogan ini biasanya ditujukan kepada para santri yang prestasi belajarnya cukup baik dan yang berminat akan suatu bahasan khusus sebagai bekal mempersiapakan diri sebagai penerus kyainya.

Pola pendidikan dalam pesantren (pesantren tradisional) dilakukan secara holistik dalam arti bahwa proses belajar mengajar itu merupakan keterpaduan yang utuh dan totalitas dalam kehidupan sehari-hari sehingga persoalan yang berhubungan kapan mulai belajar, target apa yang ingin dicapai dan kapan harus selesai tidak pernahdibicarakan. Implikasinya sulit mencari dan merumuskan tujuan pendidikan pesantren secara baku yang biasa dijadikan standar umum. ${ }^{15}$

Proses belajar-mengajar di pesantren mengacu pada prinsip-prinsip pendidikan, antara lain: Pertama, berdasarkan filsafat teosentris, yaitu semua proses dalam kehidupan di muka Bumi akan kembali kepada Ilahi. Dalam konteks ini segala perbuatan terkait erat dengan hukum agama dan demi kepentingan ukhrawi; kedua, sukarela dan mengabdi. Dalam kontek ini para kyai melakukan pengabdian kepada sesamanya dalam rangka mengabdi dan beribadah kepada Allah swt.; ketiga, kearifan. Dalam konteks ini adalah berperilaku sabar, rendah hati, taat pada hukum agama dan mendatangkan kemaslahatan serta kebaikan bagi kepentingan bersama; keempat, kesederhanaan. Dalam konteks ini adalah bersikap dan berfikir secara wajar, seimbang dan tidak sombong; kelima, kolektivitas, di mana rasa kebersamaan lebih ditonjolkan sehingga rasa individualisme sangat berkurang, sehingga dalam kehidupan sehari-harinya

\footnotetext{
${ }^{15}$ Yatim, (dkk), Sejarah Perkembangan ..., h. 23
} 
'dalam hak mendahulukan kepentingan orang lain, tetapi dalam kewajiban orang harus mendahulukan kewajiban diri sendiri sebelum orang lain'; keenam, mengatur kegiatan bersama, dimana para santri dengan dibimbing oleh ustadnya melakukan kegiatan diatur secara bersama; ketujuh, kebebasan terpimpin, yakni semua makhluk memiliki atau tidak bisa keluar dari garis sunatullahnya, tetapi memiliki kecenderungan tersendiri sesuai dengan fitrahny;. kedelapan, mandiri, dalam konteks ini sejak awal santri dilatih hidup mandiri, dari memasak, mencuci pakaian sampai belajar secara mandiri; kesembilan, pesantren tempat mencari ilmu dan mengabdi. Kesepuluh, mengamalkan ajaran agama, dalam konteks setiap aktivitas komunitas pesantren harus selalu didasarkan pada rambu-rambu hukum agama; kesebelas, tanpa ijazah, dalam konteks ini yang ditekankan bukan pada formalitas ijazah yang diterima, akan tetapi pengakuan oleh masyarakat terhadap pengetahuan agamanya lebih diutamakan; dan keduabelas, restu kyai, yaitu segala perbuatan santri harus memperoleh restu dari kyainya agar memperoleh maslahat. ${ }^{16}$

Dalam perjalanannya, proses belajar di lingkungan pesantren tidak semata-mataa terfokus pada kajian kitab-kitab klasik. Salah satu kegiatan yang dianggap baru menurut kalangan kominitas pesantren adalah pengembangan masyarakat, setidaknya kalau dilihat bahwa secara kultural misi utama pesantren serta porsi kegiatannya secara global adalah dalam bidang pendidikan. ${ }^{17}$ Jika Kemudian usaha tersebut berkembang besar dan baik maka akan membantu pengembangan lingkungan sekitar pondok pesantren, dengan anggapan dan harapan pondok pesantren tersebut mampu berperan dalam hal : (1) memfungsikan pondok pesantren sebagai agen pembaharuan dan

\footnotetext{
${ }^{16}$ Zamakkhsyari Dhofier, Tradisi Pesantren: Studi tentang Pandangan Hidup Kyai (Jakarta: LP3ES, 1982), h. 62-66.

${ }^{17}$ Sahal Mahfudz, "Pengembangan Masyarakat Oleh Pesantren: Antara Fungsi dan Tantangan" dalam Manfred Oepen, dkk., Dinamika Pesantren: Dampak Pesantren Dalam Pendidikan dan Pengembangan Masyarakat (Jakarta: P3M, 1988), h. 98
} 
pengembangan di daerah sekitarnya; (2) menumbuhkan kesadaran wirausaha di kalangan santri dan masyarakat sekitar pondok pesantren; dan (3) turut serta melayani dan membantu menggairahkan perekonomian masyarakat sekitarnya.

\section{STRUKTUR DAN POLA KEKUASAAN KYAI}

Di tengah perkembangan masyarakat Indonesia pada umumnya dapat dijumpai beberapa gelar sebutan yang diperuntukan bagi ulama (kyai), misalnya di daerah Jawa Barat (Sunda) orang menyebutnya ajengan, di daerah Aceh dikenal dengan 'Teungku', di daerah Sumatera Barat biasa disebur 'Buya', di Makasar biasa di panggil 'Tofranrita', di daerah Madura disebut 'Nun' atau 'Bendara' yang biasa disingkat 'ra', di Lombok dan sekitarnya biasa dipanggil 'Tuan Guru'. Khususnya di Jawa sebutan kyai biasa disamakan dengan sunan ataupun 'susuhan'. ${ }^{18}$

Dari sudut fungsinya, kyai pada masyarakat Jawa terbagi kedalam dua kategori, yaitu : pertama, kelompok kyai yang berada pada jalur dakwah dan pendidikan (al- dakwah wa altarbiyah). Kelompok ini biasanya disebut kyai pesantren a:tau ulama pondok pesantren, dengan tugas utamanya sebagai guru dan pengajar sekaligus mubaliq (penyiar) agama. Kedua, kyai yang menduduki suatu jabatan dalam pemerintah yang biasa disebut sebagai penghulu, yaitu mereka yang aktivitas sosial keagamaannya sebagai pelaksana dalam bidang kehakiman yang menyangkut hukum (syariat) Islam.

Secara hirarki struktur jabatan penghulu di Jawa dapat dikelompokkan menjadi lima tingakatan, ${ }^{19}$ yaitu :

- Tingkat Pusat : : Penghulu ageng

\footnotetext{
${ }^{18}$ Ahmad Adaby Darban, Rifa'iyah: Gerakan Sosial Keagamaan di Pedesaan Jawa Tengah Tahun 1850 - 1982 (Yogyakarta: Program Pascasarjana UGM, 1987), h. 29.

${ }^{19}$ Ibnu Qoyim Ismail, Kyai Penghulu Jawa: Peranannya di Masa Kolonial (Jakarta: Gema Insani Press, 1997), h. 75.
} 
- Tingkat Kabupaten : Penghulu kepala/khalifah.

Sedangkan wakilnya : Ajung penghulu

- Tingkat Kawedanan : Penghulu/Naib.

Sedangkan wakilnya : Ajung penghulu

- Tingkat kecamatan : Penghulu/Naib

- Tingkat Desa $\quad$ : Modin/kaum/kayim/lebe/amil

Intensitas kyai memperlihatkan peran yang otoriter disebabkan karena kyailah sang perintis, pendiri, pengelola, pengasuh, pemimpin dan bahkan juga pemilik tunggal pesantren. ${ }^{20}$ Keberadaan kyai dalam pesantren sangat sentral sekali, dan pada tingkat tertentu kemajuan dan perkembangan pesantren tergantung pada kyai. Dengan demikian, kemajuan dan kemunduran pondok pesantren benar-benar terletak pada kemampuan kyai dalam mengatur operasionalisasi dan pelaksanaan proses belajar mengajar di pesantren, sebab kyai merupakan 'penguasa' baik dalam pengertian fisik maupun non fisik yang bertanggungjawab atas kemajuan pesantren.

Dalam konteks ini, kepemimpin kyai yang kharismatik di kalangan pondok pesantren didasarkan pada kualitas 'luar biasa'. Kata luar biasa dalam hal ini merupakan pengertian yang sangat teologis karena untuk mengidentifikasi daya tarik pribadi yang melekat pada diri seorang kyai diasumsikan bahwa ia memperoleh kekuatan tersendiri dari Sang Maha Pencipta.

Kedudukan kyai di pondok pesantren adalah sebagai pemimpin tunggal, memiliki otoritas tinggi dalam menyebarkan dan mengajarkan pengetahuan agama Islam.Tidak ada figur lain yang dapat menandingi kekuasaan kyai kecuali figur kyai yang lebih tinggi kharismanya. Kyai mempunyai posisi yang absolut, menentukan corak kepemimpinan dan perkembangan pondok

${ }^{20}$ Yasmadi, Modernisasi Pesantren: Kritik Nurcholish Madjid terhadap Pendidikan Islam Tradisional (Jakarta: Ciputat Press, 2002), h. 63. 
pesantren. Dalam konteks komunitas kyai, mereka yang yunior (kyai muda) harus menghormati kyai yang tua (senior). Dalam tradisi pesantren, status kyai juga sering kali dilihat dari factor keturunan kyai yang memiliki kharisma besar kelak keturunannya menduduki status social yang sama dengan dirinya.

Namun demikian, di sisi lain adanya keikhlasan yang muncul dari seorang kyai membawa efek munculnya pesantren sebagai suatu lembaga pendidikan yang selalu disegani dan tetap menarik tanpa dipengaruhi oleh waktu yang berkembang dan lingkungan yang mengitarinya. Dalam kondisinya yang lebih maju, kedudukan kyai dalam pondok pesantren tetap sebagai tokoh utamanya. Sebagai pemimpin, kyai adalah pemilik dan guru g utama dan secara tidak berlebihan kyai adalah "raja" dalam pesantren. Lebih jauh pengaruh kyai tidak hanya di lingkungan pesantrennya tetapi juga menyebar ke berbagai pelosok wilayah di luar pesantrennya.

Kuatnya pengaruh dari kyai tentunya tidak lepas dari pola jaringan yang terbentuk di kalangan kyai. Mengacu pada hasil penelitian Proyek Pengembangan Penelitian pada Perguruan Tinggi Agama Islam Direktorat Perguruan Tinggi Agama Islam Departemen Agama Republik Indonesia menyebutkan paling tidak ada 5 pola jaringan yang dikembangkan kyai, yaitu:

- Jaringan genealogis yang terbentuk melalui hubungan darah atau kekerabatan antara kyai yang satu dengan kyai lainnya. Bahkan tidak jarang sang kyai mengambil menantu dari salah satu santrinya yang memiliki prestasi gemilang di pondok yang ia pimpin.

- Jaringan ideologis yang terbentuk karena adanya persamaan kepentingan ideologis, baik yang bersifat pemahaman keagamaan (biasanya kalangan NU) maupun ideologi politik seperti PKB, PPP, PKU, PNU, dan sejenisnya. 
- Jaringan intelektual yang terbentuk melalui proses pembelajaran baik formal maupun nonformal antara guru (kyai) dengan murid (santri).

- Jaringan teologis. Jaringan ini terbentuk melalui kesamaan paham teologi yang diyakini dan dianut oleh para kyai, yang pada umumnya di Jawa menyakini dan mengamalkan ajaran Asy'ariyah dan Maturudiyah atau yang lebih populer dengan 'Ahl al-Sunnah wa al-Jamā'ah'.

- Jaringan spiritual yang terbentuk terutama melalui organisasi tarekat. Di Indonesia (khususnya Jawa) pada umumnya menganut tareqat Naqsabandiyah. ${ }^{21}$

\section{PENUTUP}

Mengacu pada pemaparan di atas, maka dapat diambil beberapa garis kesimpulan sebagai berikut:

- Seiring dengan terus berkembangnya pola kehidupan masyarakat di sekitar lingkungan pesantren, struktur dan pola kepemimpinan (kekuasaan) kyai di kalangan komunitas pesantren dan sekitarnya tetap memiliki tempat tersendiri, dalam arti kyai tetap menempati posisi sebagai tokoh utama sebab kyai sebagai pemimpin, pemilik dan guru utama pada pesantren yang bersangkutan.

- Tanpa menghilangkan pola kepemimpinan kharismatik, kalangan pengurus pondok pesantren tetap merespon berbagai proses modernisasi di masyarakat khususnya bidang pendidikan dan perubahan-perubahan sosial ekonomi yang berlangsung dalam masyarakat Indonesia sejak beberapa dekade ini paling tidak mencakup beberapa hal, yaitu : Pertama, adanya pembaharuan substansi atau isi pendidikan pesantren dengan memasukan subjek-subjek umum disamping materi pokok bidang keagamaan; kedua, adanya pembaharuan metodologi seperti sistem klasikal,

\footnotetext{
${ }^{21}$ Suwito, Jaringan Intelektual Kyai ..., h. 134-135.
} 
penjejangan; ketiga, pembaruan kelembagaan seperti kepemimpinan dan administrasi pengelolaan; dan keempat, pembaruan fungsi tidak hanya fungsi pendidikan, tetapi berkembang mencakup beragam fungsi sosial ekonomi seperti : pertanian, industri kecil dan koperasi pesantren.

- Keberadaan struktur dan pola kekuasaan (kepemimpinan) kyai dalam hasanah pesantren tetap berkesinambungan karena kyai memiliki jaringan sosial baik secara intern (pesantren) maupun secara ektern (dengan dunia luar pesantren), meliputi jaringan genealogis, jaringan ideologis, jaringan intelektual, jaringan teologis, dan jaringan spiritual.

\section{DAFTAR PUSTAKA}

Darban, Ahmad Adaby, Rifa'iyah: Gerakan Sosial Keagamaan di Pedesaan Jawa Tengah Tahun 1850-1982, Yogyakarta: Program Pasca Sarjana UGM, 1987.

Ghazali, M. Bahri, Pendidikan Pesantren Berwawasan Lingkungan, Jakarta: Penerbit Pedoman Ilmu Jaya, t.th.

Hasbullah, Sejarah Pendidikan Islam Di Indonesia: Lintas Sejarah Pertumbuhan dan Perkembangan, Cet. ke-2, Jakarta: Raja Grafindo Persada, 1996.

Ismail, Faisal, Paradigma Kebudayaan Islam : Studi Kritis dan Refleksi Historis, Cet.ke-2, Yogyakarta: Titian Ilahi Press, 1997.

Ismail, Ibnu Qoyim, Kyai Penghulu Jawa : Peranannya di Masa Kolonial, Jakarta: Gema Insani Press, 1997.

Kartodirdjo, Sartono, Kepemimpinan dalam Sejarah Indonesia, Yogyakarta: BPA UGM, 1974.

Madjid, Nurcholish, Kaki Langit Peradaban Islam, Jakarta Paramadina, 1997

Mahfudz, Sahal, "Pengembangan Masyarakat Oleh Pesantren : Antara Fungsi dan Tantangan", dalam Manfred Oepen, dkk., Dinamika Pesantren: Dampak Pesantren dalam Pendidikan dan Pengembangan Masyarakat. Jakarta P3M, 1988. 
Paul, Johson Doyle, Teori Sosiologi Klasik dan Modern, terj. Robert M. Z. Lawang, Jakarta: PT Gramedia, 1994.

Rahim, Husni, Direktori Pondok Pesantren, Jakarta: Proyek Peningkatan Pondok Pesantren Tahun Anggaran 2000 Direktorat Jenderal Pembinaan Kelembagaan Agama Islam Departemen Agama RI, 2000.

Soemardjan, Selo \& Soelaeman Soemardi, Setangkai Bunga Sosiologi, Jakarta: Lembaga Penerbit Fakultas Ekonomi Universitas Indonesia, 1974.

Steenbrink, Karel A., Pesantren Madrasah Sekolah : Pendidikan Islam dalam Kurun Moderen, terj. Abdurrahman, Jakarta: LP3ES, 1994.

Sukamto, "Kepemimpinan dan Struktur Kekuasaan Kyai : Studi Kasus Pondok Pesantren Darul Ulum Jombang" dalam Prisma No. 4 April 1997.

Suryono Soekanto, Kamus Sosiologi, Jakarta: PT Raja Grafindo Persada, 1993.

Suwito, Jaringan Intelektual Kyai Pesantren di Jawa - Madura Abad XX, Jakarta: Proyek Pengembangan Penelitian pada Perguruan Tinggi Agama Islam Direktorat Perguruan Tinggi Agama Islam Departemen Agama RI, 2001.

Suma, Amin, dkk, Pondok Pesantren Al-Zaytun : Idealitas, Realitas dan Kontroversi, Jakarta: Lembaga Penelitian Universitas Islam Negeri (UIN) Syarif Hidayatullah, 2002.

Yasmadi, Modernisasi Pesantren: Kritik Nurcholish Madjid terhadap Pendidikan Islam Tradisional, Jakarta: Ciputat Press, 2002.

Yatim, Badri, (dkk), Sejarah Perkembangan Madrasah, Jakarta: Direktorat Jenderal Pembinaan Kelembagaan Agama Islam Departemen Agama RI, 1999. 